\title{
Viability of Sporulated Oocysts of Neospora caninum After Exposure to Different Physical and Chemical Treatments
}

\author{
Author(s): Aldo F. Alves Neto , Luciana A. Bandini , Sandra M. Nishi, Rodrigo M. Soares , David \\ Driemeier, Nadia A. B. Antoniassi, Gereon Schares , and Solange M. Gennari \\ Source: Journal of Parasitology, 97(1):135-139. 2011. \\ Published By: American Society of Parasitologists \\ DOI: http://dx.doi.org/10.1645/GE-2571.1 \\ URL: http://www.bioone.org/doi/full/10.1645/GE-2571.1
}

BioOne (www.bioone.org) is a nonprofit, online aggregation of core research in the biological, ecological, and environmental sciences. BioOne provides a sustainable online platform for over 170 journals and books published by nonprofit societies, associations, museums, institutions, and presses.

Your use of this PDF, the BioOne Web site, and all posted and associated content indicates your acceptance of BioOne's Terms of Use, available at www.bioone.org/page/terms of use.

Usage of BioOne content is strictly limited to personal, educational, and non-commercial use. Commercial inquiries or rights and permissions requests should be directed to the individual publisher as copyright holder. 


\title{
VIABILITY OF SPORULATED OOCYSTS OF NEOSPORA CANINUM AFTER EXPOSURE TO DIFFERENT PHYSICAL AND CHEMICAL TREATMENTS
}

\author{
Aldo F. Alves Neto*, Luciana A. Bandini, Sandra M. Nishi†, Rodrigo M. Soares, David Driemeierł, Nadia A. B. Antoniassił, \\ Gereon Schares $\S$, and Solange M. Gennari\| \\ Faculdade de Medicina Veterinária e Zootecnia da Universidade de São Paulo, Av. Prof. Orlando M. de Paiva, 87, Cidade Universitária, CEP \\ 05508-270, São Paulo, SP, Brazil. e-mail: sgennari@usp.br
}

\begin{abstract}
The aim of the present study was to evaluate the viability of Neospora caninum sporulated oocysts after various chemical and physical treatments. Bioassays in gerbils and molecular techniques (PCR-RFLP) were used for identification of the oocysts shed by experimentally infected dogs. Sporulated oocysts were purified and divided into 11 treatment groups as follows: absolute ethanol for $1 \mathrm{hr}$; $20 \mathrm{C}$ for $6 \mathrm{hr}$; $4 \mathrm{C}$ for $6 \mathrm{hr} ; 60 \mathrm{C}$ for $1 \mathrm{~min}$; $100 \mathrm{C}$ for $1 \mathrm{~min}$; $10 \%$ formaldehyde for $1 \mathrm{hr} ; 10 \%$ ammonia for $1 \mathrm{hr} ; 2 \%$ iodine for $1 \mathrm{hr}$; $10 \%$ sodium hypochlorite for $1 \mathrm{hr}$; $70 \%$ ethanol for $1 \mathrm{hr}$; and one group was left untreated and kept as a positive control. All chemical treatments were performed at room temperature $(37 \mathrm{C})$. A total of 33 gerbils, or 3 gerbils per treatment, were used for bioassays. After treatment, the oocysts were divided into aliquots of 1,000 oocysts and orally administered to gerbils. After 63 days, the gerbils were anesthetized and killed with $0.2 \mathrm{ml}$ of $\mathrm{T} 61$; blood and tissue samples were collected for serological (IFAT and western blotting), molecular (real-time PCR), histopathology, and immunohistochemical tests. Treatments were considered effective only if all 5 detection techniques tested negative. High temperatures at $100 \mathrm{C}$ for $1 \mathrm{~min}$ and $10 \%$ sodium hypochlorite for $1 \mathrm{hr}$ were the only treatments that met this condition, effectively inactivating all oocysts.
\end{abstract}

Neospora caninum, a cyst-forming coccidian parasite, affects a wide range of host species and is one of the most important infectious causes of abortion in cattle. Dogs are the definitive hosts of the parasite and shed fecal oocysts; oocysts are approximately $11.7 \times 11.3 \mu \mathrm{m}$ in size and become infectious after sporulation, at which time they acquire a spherical to subspherical shape. Oocysts have 2 sporocysts $(7.0-8.0 \times 2.0-3.0 \mu \mathrm{m})$, each of which is, in turn, composed of 4 sporozoites (Lindsay et al., 1999).

Studies conducted mainly with Eimeria spp. show that, apart from lipids and carbohydrates, the cellular walls of coccidian oocysts possess a highly structured and resistant protein matrix (Mai et al., 2009). This tough cellular wall provides an effective barrier for sporozoites against mechanical and chemical threats (Belli et al., 2006). Resistance to proteolytic substances and impermeability to aqueous solutions, including various detergents and disinfectants, also creates real challenges for controlling coccidian infection in domestic animals (Mai et al., 2009). Lipidsoluble substances and small molecules are permeable to oocyst cell walls, as has been observed with ammonia and methylbromide (Kuticic and Wikerhauser, 1996).

Although several studies have dealt with the resistance and viability of other major coccidia such as Toxoplasma gondii (Frenkel et al., 1975; Dubey and Beattie, 1988; Dubey, 1998; Lindsay et al., 2003) and Sarcocystis neurona (Dubey et al., 2002), there is sparse information in the literature concerning the viability of $N$. caninum oocysts. The objective of the present study is to assess the resistance of sporulated $N$. caninum oocysts to different temperature conditions, treatments by disinfectants, and exposure times.

Received 21 June 2010; revised 26 August 2010; accepted 30 August 2010.

* Universidade Paulista, São Paulo, SP, Brazil.

$\dagger$ Escola de Medicina Veterinária, Universidade Federal da Bahia, Salvador, BA, Brazil.

\#Faculdade de Medicina Veterinária, Universidade Federal do Rio Grande do Sul, Porto Alegre, RS, Brazil.

$\S$ Federal Research Institute for Animal Health, Institute of Epidemiology, Wusterhausen, Germany.

\|To whom correspondence should be addressed.

DOI: 10.1645/GE-2571.1

\section{MATERIALS AND METHODS}

\section{Production of $\boldsymbol{N}$. caninum oocysts}

Oocysts used in the physical and chemical treatments were obtained from experimentally infected dogs through ingestion of naturally $N$. caninum-infected buffalo brains. Briefly, buffaloes were tested for anti- $N$. caninum antibodies using an indirect immunofluorescence antibody test (IFAT $\geq 100$ ) as described by Dubey et al. (1988). Brains from the seropositive animals were collected and fed to 3,2-mo-old domestic dogs (Canis familiaris). Each pup consumed 1 brain administered in equal portions throughout 2 consecutive days. Excepting a 24-hr fasting period prior to ingestion of the brains, the dogs received daily rations of appropriate commercial dog food and water ad libitum throughout the experimental period. They were maintained in individual stalls and vaccinated against parvovirus, parainfluenza, corona virus, leptospirosis, and canine distemper (Duramune ${ }^{\circledR}$ Max5CvK, Fort Dodge, Campinas, SP, Brazil) prior to $N$. caninum infection.

On the third and fourth day post-ingestion (dpi), 2 dogs were imunosuppressed with an intramuscular injection of $80 \mathrm{mg}$ of methylprednisolone acetate (Depo-Medrol ${ }^{\circledR}$, Pfizer, São Paulo, SP, Brazil). After $5 \mathrm{dpi}$ and beyond, feces of each dog were collected daily and sampled for oocysts resembling the morphology of $N$. caninum or Hammondia heydorni (in the following referred to Neospora-Hammondia-like oocysts) using a sugar flotation technique (Ogassawara and Benassi, 1980).

Positive samples were mixed in $2 \%$ potassium dichromate solution and stored in bottles at $27 \mathrm{C}$ for 14 days to induce sporulation. After this, sporulated oocysts were maintained at $4 \mathrm{C}$. Prior to their use, oocysts were purified and potassium dichromate was removed with 3 successive washes of distilled water and centrifugation.

Purified material was homogenized and the number of oocysts determined by triplicate measurements using a Neubauer counting chamber. The number of oocysts for inocula was determined by the average number of oocysts obtained at the triplicates. The oocysts were maintained at $4 \mathrm{C}$ for no longer than 87 days from the time they were eliminated in feces until gerbil inoculation.

\section{Identification of oocysts}

Prior to the chemical and physical treatments, it was confirmed that the oocysts were $N$. caninum using molecular (PCR-RFLP) and biological (gerbil bioassay) methods. PCR-RFLP was performed as described by Monteiro et al. (2008) using primers targeting the Hsp70 coding gene. The species-specific enzymes Stul and $\mathrm{Kpnl}$ were used to digest target regions of $N$. caninum and $H$. heydorni, respectively. The PCR amplification and digestion pattern were visualized after electrophoresis in a $2.5 \%$ agarose gel stained with ethidium bromide. Positive controls were extracted from known samples of $N$. caninum (Nc-1) and oocysts of $H$. heydorni (stock HheBR) that were previously characterized by molecular methods (Monteiro et al., 2008) and compared to sampled material. 


\section{Oocysts treatments}

Eleven tubes with approximately 3,000 sporulated $N$. caninum oocysts each were submitted to 1 of the following chemical or physical treatment groups: (G1) absolute ethanol at $24 \mathrm{C}$ for $1 \mathrm{hr}$; (G2) $-20 \mathrm{C}$ in saline solution for $6 \mathrm{hr}$; (G3) $4 \mathrm{C}$ in saline solution for $6 \mathrm{hr}$; $(\mathrm{G} 4) 60 \mathrm{C}$ in saline solution for $1 \mathrm{~min}$; (G5) $100 \mathrm{C}$ in saline solution for $1 \mathrm{~min}$; (G6) $10 \%$ formalin at $24 \mathrm{C}$ for $1 \mathrm{hr}$; (G7) $10 \%$ ammonia at $24 \mathrm{C}$ for $1 \mathrm{hr}$; (G8) $2 \%$ iodine at $24 \mathrm{C}$ for $1 \mathrm{hr}$; (G9) $10 \%$ sodium hypochlorite at $24 \mathrm{C}$ for $1 \mathrm{hr}$; (G10) $70 \%$ ethanol at $24 \mathrm{C}$ for $1 \mathrm{hr}$; and (G11, control) saline solution at ambient temperature, $24 \mathrm{C}$.

For the chemical inactivation tests (G1, G6, G7, G9, and G10), $475 \mu 1$ of the oocyst suspensions were mixed in $10 \mathrm{ml}$ of the disinfectant solution and incubated for $1 \mathrm{hr}$ at $24 \mathrm{C}$. Following treatment, oocysts were twice washed with saline solution and centrifuged to remove chemical residues. For thermal resistance tests (G2-G5, G11) oocysts were suspended in saline solution and microtubes were kept at $-20 \mathrm{C}, 4 \mathrm{C}, 60 \mathrm{C}$, and $100 \mathrm{C}$ according to the period of incubation mentioned above.

\section{Gerbil bioassay}

Thirty-three gerbils were divided into 11 groups of 3. After the treatments, inocula containing approximately 1,000 oocysts were orally administered to each gerbil with the aid of a feeding tube. Gerbil groups G1 to G10 received oocysts from the corresponding oocyst treatments, while G11 received the untreated control oocysts. Each group was maintained in a separate cage that was sanitized weekly. Gerbils were observed daily throughout the entire experimental period and received adequate daily rations and water ad libitum.

After a 63-day period, the gerbils were anesthetized via an intraperitoneal injection of a mixture of $0.015 \mathrm{ml}$ of $2 \%$ xylazine (Kensol ${ }^{\circledR}$, Konig, São Paulo, SP, Brazil) and $0.03 \mathrm{ml}$ of $10 \%$ ketamine (Vetaset ${ }^{\circledR}$, Fort Dodge). After anesthesia, $1.0 \mathrm{ml}$ of blood was collected by intracardiac puncture. Serum samples were divided into aliquots and kept at $-4 \mathrm{C}$ until later use. After blood collection, the gerbils were killed with $0.2 \mathrm{ml}$ of T61 ${ }^{\circledR}$ (Intervet, São Paulo, SP, Brazil) and necropsy was performed to remove the brain, heart, liver, spleen, and thigh muscle. Half of each tissue was placed in a vial with buffered formalin $(100 \mathrm{ml}$ of $40 \%$ formaldehyde, $900 \mathrm{ml}$ of distilled $\mathrm{H}_{2} \mathrm{O}, 4 \mathrm{~g}$ of $\mathrm{NaH}_{2} \mathrm{PO}_{4}$, and $6.5 \mathrm{~g}$ of $\mathrm{Na}_{2} \mathrm{HPO}_{4}$ ) for histopathology and immunohistochemical (IHC) diagnosis. An additional aliquot of each tissue was placed in microtubes and frozen at $-20 \mathrm{C}$ for real-time PCR analysis.

Fresh brain smears were also examined, for detection of $N$. caninum cysts, using a 100 -fold magnification in light microscopy.

Animal management and veterinarian procedures with dogs and gerbils were approved by, and in accordance to, the Animal Use Ethics Committee of the Faculty of Veterinary Medicine of the University of São Paulo (protocol number 1187/2007).

\section{IFAT of gerbil serum}

Gerbil sera were tested for anti- $N$. caninum antibodies by indirect immunofluorescence antibody tests (Dubey et al., 1988) using secondary fluorescein isothiocyanate-labeled anti-gerbil antibodies (Immunology Consultants Laboratory, Newberg, Oregon) and intact tachyzoites of $N$. caninum (strain NC-1) as antigen. The cutoff was set at 1:50 (Dubey et al., 1988) and the samples were tested at dilutions of $1: 50$ and 1:100.

\section{Western blotting (WB) of gerbil serum}

Nc-1 strains of N. caninum (Dubey et al., 1988) were maintained in Vero cell cultures and purified following the protocol of Schares et al. (1998, 1999). Tachyzoites obtained from the culture were frozen at $-80 \mathrm{C}$ until needed for WB.

Affinity chromotography employing monoclonal antibodies $\mathrm{mAb}$ 4.15.15, as described by Schares et al. (2000), was used to purify $N$. caninum surface antigens p38 (NcSRS2).

Whole tachyzoite antigens of $N$. caninum and purified surfaced antigens (Schares et al., 1998) were used for the WB test. Pellets containing $4 \times 10$ $N$. caninum tachyzoites and purified p38 proteins $(0.05 \mu \mathrm{g})$ were incubated in buffer (2\% [w/v] SDS, $10 \%$ [v/v] glycerol, $62 \mathrm{mM}$ Tris-HCl, $\mathrm{pH} 6.8)$ for $1 \mathrm{~min}$ at $94 \mathrm{C}$ and separated in polyacrylamide gel (SDS) at $12 \%(\mathrm{w} / \mathrm{v}$; $60 \times 70 \times 1 \mathrm{~mm}$ in size). The antigens were subsequently transferred to PVDF membranes (Immobilon-P, Millipore, Billerica, Massachusetts) which, after the transfer, were blocked with PBS-TG (PBS with $0.05 \%$ $[\mathrm{v} / \mathrm{v}]$ ), Tween 20 (Sigma, St. Louis, Missouri), and 2\% liquid fish gelatin (v/v) (Serva, Heidelberg, Germany). The membranes were cut into strips for later examination.

When using total antigen of $N$. caninum, the reactivity of sera with immunodominant antigens of $N$. caninum tachyzoites (Nc-IDA) of 29, 30, 33 , and $37 \mathrm{kDa}$ was recorded (Schares et al., 2000). For the WB employing the purified $\mathrm{p} 38$ protein $(\mathrm{NcSRS} 2)$, reactivity of the sera with a single band at $38 \mathrm{kDa}$ was recorded.

To detect anti- $N$. caninum antibodies, incubations of the WB strips followed the methodology described by Schares et al. (1988), with modifications. Sera were diluted at 1:100 in PBS-TG and serum from an experimentally infected gerbil was used as a positive control (Schares et al., 2005).

\section{Histopathology and immunohistochemistry (IHC)}

Tissue sections stained with hematoxylin and eosin (H\&E) were employed for the histological examination. Neospora caninum detection was performed by an IHC test using anti- $N$. caninum primary antibody (VMRD, Pullman, Washington).

The tissues were initially incubated in $3 \%$ hydrogen peroxide solution for $10 \mathrm{~min}$ to block endogenous peroxidase. Antigen retrieval was performed using $0.1 \%$ trypsin for $10 \mathrm{~min}$ at room temperature $(37 \mathrm{C})$, followed by heat (microwave on full power $2 \mathrm{~min}$ ) with the slides immersed in citrate buffer, $\mathrm{pH} 6.0\left(1 \mathrm{~L}\right.$ of distilled water, $2.1 \mathrm{~g} \mathrm{C}_{6} \mathrm{H}_{8} \mathrm{O}_{7}$; adjusted to $\mathrm{pH} 6.0$ with $0.5 \% \mathrm{NaOH})$. Nonspecific labeling was reduced by applying $5 \%$ reduced-fat milk for $15 \mathrm{~min}$. The primary antibody was applied for $1 \mathrm{hr}$ at $37 \mathrm{C}$, followed by $20 \mathrm{~min}$ of the secondary biotinylated antibody and avidin-peroxidase conjugate solution (Dako do Brasil, São Paulo, Brazil), also at $37 \mathrm{C}$. Labeling was performed using the chromogen 3, 5-diaminobenzidine tetra-hydrochloride as a substrate (DAB, Dako do Brasil) for 5 to $10 \mathrm{~min}$. Hematoxylin applied for $1 \mathrm{~min}$ was used as a counter stain (Mills, 1992).

\section{Real-time PCR}

Brain and heart samples of each gerbil were fragmented and macerated in a mortar and pestle with liquid nitrogen. The tissues were then homogenized with DNAzol ${ }^{\circledR}$ (DNAzol Reagent, GIBCO, Auckland, New Zealand) until cellular lysis was complete. Subsequently, the material was centrifuged at $10,000 \mathrm{~g}$ for $10 \mathrm{~min}$ to remove cellular debris. Absolute ethanol was used to precipitate nuclear material and subsequently extracted from the supernatant. After several washes with $70 \%$ ethanol, the DNA was solubilized in $8 \mathrm{mM} \mathrm{NaOH}$ solution. DNA concentration and quality were estimated by a spectrophotometer reading at $260 \mathrm{~nm}$ and $280 \mathrm{~nm}$ (BioPhotometer, Eppendorf, Hamburg, Germany).

Fifty nanograms of DNA were used in each amplification reaction using universal real-time PCR buffer (TaqMan Universal PCR Master Mix, Applied Biosystems, Carlsbad, California), with a specific set of primers and probe for N. caninum (gene NC5) and an endogenous control 18S (Eukariotic 18S rRNA Endogenous Control, Applied Biosystems). Oligonucleotide sequences $\left(5^{\prime}-3^{\prime}\right)$ for gene NC5, based on Genbank Accession number AY665719, were: Sense GCG GAC GTG TCG TTG TTG; Anti-sense GTT CAC ACA CTA TAG CCA CAA ACA A; and Probe (VIC-TAMRA) CCT GCG GCA GCA AGG CTC CTT.

DNA from tachyzoites of $N$. caninum (strain Nc-1) and Milli-Q water served as positive and negative controls, respectively. Amplifications were performed using Applied Biosystems 7500 Real-Time PCR System equipment and subjected to $50 \mathrm{C}$ for $2 \mathrm{~min}, 95 \mathrm{C}$ for $10 \mathrm{~min}, 40$ cycles at $95 \mathrm{C}$ for $15 \mathrm{sec}$, and $60 \mathrm{C}$ for $1 \mathrm{~min}$. Amplification curves were analyzed by Sequence Detection Software (SDS, v1.3, Applied Biosystems).

Reactions were considered positive if the fluorescent signal increased during amplification and negative if the florescent signal remained at the same basal level observed during the beginning of the amplification cycles.

Each gerbil tissue was analyzed in duplicate.

\section{RESULTS}

One of the immunosuppressed dogs died on $5 \mathrm{dpi}$ and the other shed Neospora-Hammondia-like oocysts from 8 to $17 \mathrm{dpi}$. The dog that had not received an immunosuppressive treatment failed to shed oocysts. The oocysts present in dog feces were analyzed 

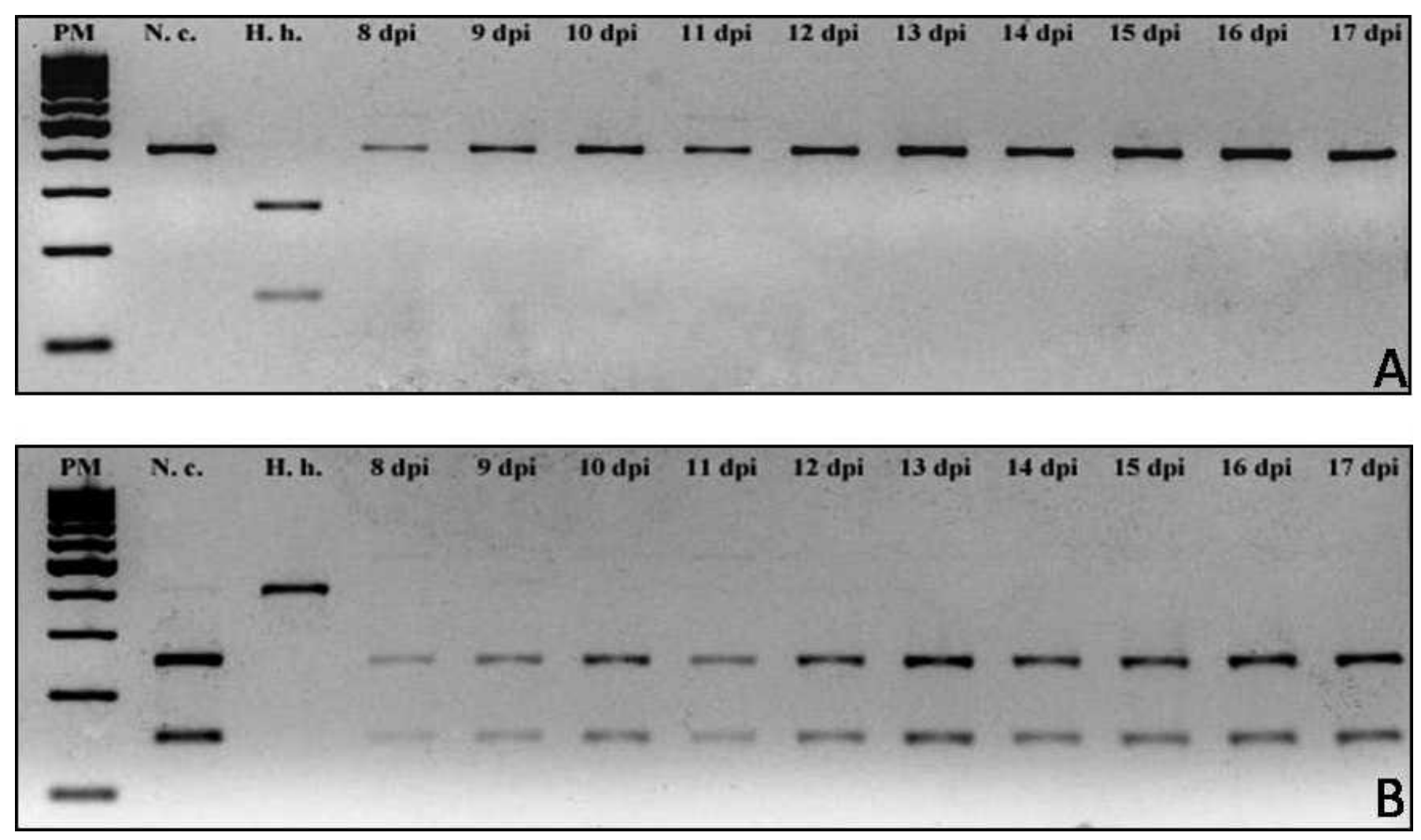

FIgURE 1. Agarose gel electrophoresis of the PCR-RFLP products amplified from Hammondia-like oocysts using primers directed to the HSP 70 coding sequences and the restriction enzymes KpnI and StuI from 8 to 17 dpi. (A) KpnI enzyme - N.c.: positive control for N. caninum (400 bp); H.h.: positive control for $H$. heydorni $(136+264$ bp). (B) Stul enzyme - N.c.: positive control for N. caninum (150 + 250 bp); H.h.: positive control for H. heydorni (400 bp). PM: molecular weight; weight marker (100 bp).

separately each day and confirmed to be $N$. caninum by PCRRFLP (Fig. 1).

Table I shows the results of the gerbil bioassay evaluating the viability of $N$. caninum oocysts after the physical and chemical treatments. Two treatments, $100 \mathrm{C}$ for $1 \mathrm{~min}(\mathrm{G} 5)$ and $10 \%$ hypochlorite at ambient temperatures for $1 \mathrm{hr}(\mathrm{G} 9)$, were the only ones to successfully inactivate oocysts, as confirmed by the 5 tests performed.

Via histologic examination, only gerbil 12 from G4 presented moderate suppurative meningitis in the brain, with deposition of fibrin and bacterial clots and discrete focal mononuclear encephalitis. In the same animal, $N$. caninum were observed in the interior of inflammatory cells of the brain by IHC.

Tissue cysts were not detected in the brain of the gerbils by light microscope examination.

By the real-time PCR, tissue samples from 7 (3 controls, 1 gerbil from G3, 2 from G4, and 1 from G7) of the 33 gerbils were positive to $N$. caninum DNA. All positive samples were from brain material.

The serological techniques (WB and IFAT) presented similar results, with all gerbils from G5 and G9, and 2 from G8, negative. The remaining gerbils were all positive.

\section{DISCUSSION}

Oocysts used in the assay were confirmed to be $N$. caninum by molecular and biological methods. Rather than pooling samples, oocysts shed in feces were analyzed daily, with each analysis conferring similar results. After identification was firmly established through repeated analysis, the oocysts were pooled from different samples in order to prepare the numerous inoculations.

Not all tests were equally effective in detecting $N$. caninum. Although 5 brain smears were performed per gerbil, none of the 30 experimentally infected gerbils was found to have brain tissue cysts. In a study on T. gondii infections, Dubey (1988) predicted a frequency of 1 cyst per $50 \mathrm{~g}$ of tissue in large-bodied mammals. Similar data for $N$. caninum infection do not exist. However, given that $N$. caninum cysts are rarely observed in organs other than the brain, expected frequencies may be much less than in $T$. gondii infection. Furthermore, the number of $N$. caninum cysts in tissues may vary depending on the isolate (Gondim et al., 2001; Pena et al., 2007).

The detection of $N$. caninum stages by IHC also showed low sensitivity, with only 1 gerbil from G4 ( $-60 \mathrm{C}$ for $1 \mathrm{~min}$ ) testing positive. However, molecular (real-time PCR) and serological (IFAT and WB) techniques proved to be more sensitive, suggesting their effectiveness in trials utilizing gerbils as experimental models. All control gerbils receiving oocysts without treatment resulted in positives for $N$. caninum for all 3 tests. Real-time PCR tests were positive only for brain tissues of 7 gerbils. In the heart samples, $N$. caninum was not found, reinforcing the importance of examining brain samples. 
TABLE I. Results of direct examination for tissue cysts of $N$. caninum in the brain (cysts), immunohistochemistry tests (IHC), indirect immunofluorescence antibody tests (IFAT $\geq 100$ ), western blotting (WB), and realtime PCR (PCR) in gerbils that had received different treatments $(\mathrm{G} 1-$ G11) and were inoculated with 1,000 oocysts ( $\mathrm{P}=$ Positive, $\mathrm{N}=$ Negative $)$.

\begin{tabular}{|c|c|c|c|c|c|c|c|}
\hline Group & Treatment & $\begin{array}{c}\text { Gerbil } \\
\text { No. }\end{array}$ & Cysts & IHC & IFAT & WB & PCR \\
\hline \multirow[t]{3}{*}{1} & Absolute & 1 & $\mathrm{~N}$ & $\mathrm{~N}$ & $\mathrm{P}$ & $\mathrm{P}$ & $\mathrm{N}$ \\
\hline & Alcohol & 2 & $\mathrm{~N}$ & $\mathrm{~N}$ & $\mathrm{P}$ & $\mathrm{P}$ & $\mathrm{N}$ \\
\hline & $24 \mathrm{C} / 1 \mathrm{hr}$ & 3 & $\mathrm{~N}$ & $\mathrm{~N}$ & $\mathrm{P}$ & $\mathrm{P}$ & $\mathrm{N}$ \\
\hline \multirow[t]{3}{*}{2} & $-20 \mathrm{C} / 6 \mathrm{hr}$ & 4 & $\mathrm{~N}$ & $\mathrm{~N}$ & $\mathrm{P}$ & $\mathrm{P}$ & $\mathrm{N}$ \\
\hline & & 5 & $\mathrm{~N}$ & $\mathrm{~N}$ & $\mathrm{P}$ & $\mathrm{P}$ & $\mathrm{N}$ \\
\hline & & 6 & $\mathrm{~N}$ & $\mathrm{~N}$ & $\mathrm{P}$ & $\mathrm{P}$ & $\mathrm{N}$ \\
\hline \multirow[t]{3}{*}{3} & $4 \mathrm{C} / 6 \mathrm{hr}$ & 7 & $\mathrm{~N}$ & $\mathrm{~N}$ & $\mathrm{P}$ & $\mathrm{P}$ & $\mathrm{N}$ \\
\hline & & 8 & $\mathrm{~N}$ & $\mathrm{~N}$ & $\mathrm{P}$ & $\mathrm{P}$ & $\mathrm{N}$ \\
\hline & & 9 & $\mathrm{~N}$ & $\mathrm{~N}$ & $\mathrm{P}$ & $\mathrm{P}$ & $\mathrm{P}$ \\
\hline \multirow[t]{3}{*}{4} & $60 \mathrm{C} / 1 \mathrm{~min}$ & 10 & $\mathrm{~N}$ & $\mathrm{~N}$ & $\mathrm{P}$ & $\mathrm{P}$ & $\mathrm{P}$ \\
\hline & & 11 & $\mathrm{~N}$ & $\mathrm{~N}$ & $\mathrm{P}$ & $\mathrm{P}$ & $\mathrm{P}$ \\
\hline & & 12 & $\mathrm{~N}$ & $\mathrm{P}$ & $\mathrm{P}$ & $\mathrm{P}$ & $\mathrm{N}$ \\
\hline \multirow[t]{3}{*}{5} & $100 \mathrm{C} / 1 \mathrm{~min}$ & 13 & $\mathrm{~N}$ & $\mathrm{~N}$ & $\mathrm{~N}$ & $\mathrm{~N}$ & $\mathrm{~N}$ \\
\hline & & 14 & $\mathrm{~N}$ & $\mathrm{~N}$ & $\mathrm{~N}$ & $\mathrm{~N}$ & $\mathrm{~N}$ \\
\hline & & 15 & $\mathrm{~N}$ & $\mathrm{~N}$ & $\mathrm{~N}$ & $\mathrm{~N}$ & $\mathrm{~N}$ \\
\hline \multirow[t]{3}{*}{6} & $10 \%$ & 16 & $\mathrm{~N}$ & $\mathrm{~N}$ & $\mathrm{P}$ & $\mathrm{P}$ & $\mathrm{N}$ \\
\hline & Formaldehyde & 17 & $\mathrm{~N}$ & $\mathrm{~N}$ & $\mathrm{P}$ & $\mathrm{P}$ & $\mathrm{N}$ \\
\hline & $24 \mathrm{C} / 1 \mathrm{hr}$ & 18 & $\mathrm{~N}$ & $\mathrm{~N}$ & $\mathrm{P}$ & $\mathrm{P}$ & $\mathrm{N}$ \\
\hline \multirow[t]{3}{*}{7} & $10 \%$ & 19 & $\mathrm{~N}$ & $\mathrm{~N}$ & $\mathrm{P}$ & $\mathrm{P}$ & $\mathrm{N}$ \\
\hline & Ammonia & 20 & $\mathrm{~N}$ & $\mathrm{~N}$ & $\mathrm{P}$ & $\mathrm{P}$ & $\mathrm{N}$ \\
\hline & $24 \mathrm{C} / 1 \mathrm{hr}$ & 21 & $\mathrm{~N}$ & $\mathrm{~N}$ & $\mathrm{P}$ & $\mathrm{P}$ & $\mathrm{P}$ \\
\hline \multirow[t]{3}{*}{8} & $2 \%$ & 22 & $\mathrm{~N}$ & $\mathrm{~N}$ & $\mathrm{P}$ & $\mathrm{P}$ & $\mathrm{N}$ \\
\hline & Iodine & 23 & $\mathrm{~N}$ & $\mathrm{~N}$ & $\mathrm{~N}$ & $\mathrm{~N}$ & $\mathrm{~N}$ \\
\hline & $24 \mathrm{C} / 1 \mathrm{hr}$ & 24 & $\mathrm{~N}$ & $\mathrm{~N}$ & $\mathrm{~N}$ & $\mathrm{~N}$ & $\mathrm{~N}$ \\
\hline
\end{tabular}

Both WB and IFAT produced identical results. In each case, 25 of the 33 gerbils tested positive for anti- $N$. caninum antibodies.

A given treatment was considered effective only if all 5 diagnostic tests proved negative, a condition only observed in 2 groups, G5 (100 C for $1 \mathrm{~min})$ and G9 (10\% sodium hypochlorite for $1 \mathrm{hr}$ ). In other treatments, at least 1 positive outcome after the inoculations of 3 gerbils was observed.

While $10 \%$ sodium hypochlorite for $1 \mathrm{hr}$ at room temperature proved effective, shorter time periods should be tested to avoid prolonged exposure times in closed environments, especially if animals are present in the same area. The diversity of dilutions that are commercially available makes it difficult to establish specific guidelines for proper use in controlling $N$. caninum. Nonetheless, knowledge of the various dilutions, and their application times, should be further studied before being discarded as a practical solution. In contrast, high temperatures, either from flame, steam, or water sources, for at least 1 min may be the most practical and effective form of control in a closed environment.

Dubey et al. (2002) reported that a treatment of absolute $(29.9 \%)$ ammonia hydroxide at temperatures ranging between $55 \mathrm{C}$ and $70 \mathrm{C}$ effectively inactivated $S$. neurona. In the present study, however, $10 \%$ ammonia hydroxide at room temperature was not effective. These results confirm the resistance of sporulated $N$. caninum oocysts to most chemical treatments, suggesting the use of high temperatures to inactivate sporulated oocysts.

\section{ACKNOWLEDGMENTS}

We thank Fundação de Amparo à Pesquisa do Estado de São Paulo (FAPESP), São Paulo, Brazil for financial support as well as the Conselho Nacional de Desenvolvimento Científico e Tecnológico (CNPq) for a productivity grant awarded to S. M. Gennari, D. Driemeier, and R. M. Soares.

\section{LITERATURE CITED}

Belli, S. I., N. C. Smith, and D. J. P. Ferguson. 2006. The coccidian oocyst: A tough nut to crack. Trends in Parasitology 22: 416-423.

Dubey, J. P. 1988. Long-term persistence of Toxoplasma gondii in tissues of pigs inoculated with $T$. gondii oocysts and effect of freezing on viability of tissue cysts in pork. American Journal of Veterinary Research 49: 910-913.

. 1998. Toxoplasma gondii oocyst survival under defined temperatures. Journal of Parasitology 84: 862-865.

, and C. P. Beattie. 1988. Toxoplasmosis of animals and man CRC Press, Boca Raton, Florida, 220 p.

- A. L. Hattel, D. S. Lindsay, and M. J. Topper. 1988. Neonatal Neospora caninum infection in dogs: Isolation of the causative agent and experimental transmission. Journal American Veterinary Medical Association 193: 1259-1263

, W. J. Saville, C. Sreekumar, S. K. Shen, D. S. Lindsay, H. F. J. Pena, M. C. Vianna, S. M. Gennari, and S. M. Reed. 2002. Effects of high temperature and disinfectants on the viability of Sarcocystis neurona sporocysts. Journal of Parasitology 88: 1252-1254.

Frenkel, J. K., A. Ruiz, and M. Chinchilla. 1975. Soil survival of Toxoplasma gondii in Kansas and Costa Rica. The American Journal of Tropical Medicine and Hygiene 24: 439-443.

Gondim, L. F. P., A. M. Pinheiro, P. O. Santos, E. E. Jesus, M. B Ribeiro, H. S. Fernandes, M. A. Almeida, S. M. Freire, R. Meyer, AND M. M. MCAllister. 2001. Isolation of Neospora caninum from the brain of a naturally infected dog, and production of encysted bradyzoites in gerbils. Veterinary Parasitology 101: 1-7.

Kuticic, V., and T. Wikerhauser. 1996. Studies on the effect of various treatments on the viability of Toxoplasma gondii tissue cysts and oocysts. Current Topics in Microbiology and Immunology 219: 261265.

Lindsay, D. S., M. V. Collins, S. M. Mitchell, E. A. Cole, G. J. Flick, C. N. Wetch, A. Lindquist, And J. P. Dubey. 2003. Sporulation and survival of Toxoplasma gondii oocysts in seawater. Journal of Eukaryotic Microbiology 50: 687-688.

, J. P. Dubey, and R. B. Duncan. 1999. Confirmation that the dog is a definitive host for Neospora caninum. Veterinary Parasitology 82: $327-333$.

- S. J. Upton, And J. P. Dubey. 1999. A structural study of the Neospora caninum oocyst. International Journal for Parasitology 29: $1521-1523$.

Mai, K., P. A. Sharman, R. A. Walker, M. Katrib, D. Souza, M. J. McConville, M. G. Wallach, S. Belli, D. J. Ferguson, and N. C. SмIтн. 2009. Oocyst wall formation and composition in coccidian parasites. Memórias do Instituto Oswaldo Cruz 104: 281-289.

MilLs, B. 1992. Immunohistochemistry. In Laboratory methods in histotechnology, E. B. Prophet, B. Mills, J. B. Arrington, and L. H. Sobin (eds.). Armed Forces Institute of Pathology, American Registry of Pathology, Washington, D.C., p. 247-255.

Monteiro, R. M., H. F. J. Pena, S. M. Gennari, S. L. P. Souza, L. J. Richtzenhain, and R. M. Soares. 2008. Differential diagnosis of oocysts of Hammondia-like organisms of dogs and cats by PCRRFLP analysis of 70-kilodalton heat shock protein (Hsp70) gene. Parasitology Research 103: 235-238.

Ogassawara, S., and S. Benassi. 1980. Infecção experimental de gatos com coração de bovino parasitado por Sarcocystis sp. Arquivos do Instituto Biológico 47: 27-32.

Pena, H. F. J., R. M. Soares, A. M. A. Ragozo, R. M. Monteiro, L. E. O. Yai, S. M. Nishi, and S. M. Gennari. 2007. Isolation and molecular detection of Neospora caninum from naturally infected sheep from Brazil. Veterinary Parasitology 147: 61-66.

Schares, G., J. F. Dubremetz, J. P. Dubey, A. Bärwald, A. Loyens, and F. J. Conraths. 1999. Neospora caninum: Identification of 19-, 
38-, and 40-kDa surface antigens and a 33-kDa dense granule antigen using monoclonal antibodies. Experimental Parasitology 92: 109-119.

, N. Pantchev, D. Barutzki, A. O. Heydorn, C. Bauer, and F. J. ConRaths. 2005. Oocysts of Neospora caninum, Hammondia hammondi, Toxoplasma gondii and Hammondia hammondi in faeces collected from dogs in Germany. International Journal for Parasitology 35: $1525-1537$.
M. Peters, R. Wurm, A. Bärwald, and F. J. Conraths. 1998. The efficiency of vertical transmission of Neospora caninum in dairy cattle analysed by serological techniques. Veterinary Parasitology 80: 87-98.

, M. Rauser, P. Söndgen, P. Rehberg, A. Bärwald, J. P. Dubey, R. Edelhofer, and F. J. ConRaths. 2000. Use of purified tachyzoite surface antigen p38 in an ELISA to diagnose bovine neosporosis. International Journal for Parasitology 30: 1123-1130. 